\title{
Tidal freshwater wetland zonation: seed and seedling dynamics
}

\author{
Mary A. Leck, ${ }^{*}$, Robert L. Simpson ${ }^{\text {b }}$ \\ 'Biology Department, Rider College, 2083 Lawrenceville Road, Lawrenceville, NJ 08648, USA \\ 'Natural Sciences Department, University of Michigan-Dearborn, Dearborn, MI 48128, USA
}

(Accepted 9 August 1993)

\begin{abstract}
Zonation patterns of seed rain (input), persistent seed bank (seeds persisting for 1 year or longer), field seedlings, and seed production were studied in a New Jersey tidal freshwater wetland along transects extending from a tidal stream bank $30 \mathrm{~m}$ into the high marsh. Species diversity was highest along the stream channel and lowest at the farthest high marsh sites. Seed rain and persistent seed bank densities were similar across the transect. Although species composition varied considerably among life history categories, generally field seedlings mirrored the species composition of the seed rain. Seed rain, seed bank, seedlings observed in the field, and seed production patterns varied between species, across sites for a species, and between years. Sites varied in the proportion of estimated seed production represented as seedlings either in greenhouse (5-99\%) or field (2-24\%) samples. Tidal transport influenced dispersal of seeds and the persistent seed bank.
\end{abstract}

\section{Introduction}

Seed banks are important to tidal freshwater wetland vegetation dynamics (Simpson et al., 1983; Leck and Simpson, 1987; Leck, 1989), in part because annuals are an important component of the vegetation. During spring germination considerable depletion of the seed bank occurs (Leck and Simpson, 1987). Dependence on yearly seed bank renewal varies with species (Leck and Simpson, 1987) and is related to seed bank strategy (sensu Thompson and Grime, 1979), with some species having transient seed banks and others having persistent seed banks which are present for more than 1 year.

The zonation pattern of the vegetation along stream channels is reflected in the composition of the seed bank, although dispersal readily occurs (Parker and Leck, 1985). In fact, in all of our seed bank studies (Leck and Graveline, 1979; Parker and Leck, 1985; Leck and Simpson, 1987), a strong correlation existed between the extant vegetation and the composition of the seed bank-unlike what may occur in other wetlands (Van der Valk, 1981; Leck, 1989).

*Corresponding author. 
We examined relationships between the seed rain (seed input), persistent seed bank, field seedlings, and seed production during 1 year and the seed bank and recruitment in the following year to determine if patterns were similar along a tidal gradient from the stream channel to the high marsh. Little seems to be known about the relationship of seed production and dispersal (seed rain and/or seed input) to the seed bank and to the vegetation (Leck, 1989).

\section{Vegetation}

Distribution of species varies relative to stream channels (Simpson et al., 1983). In each zone, both annuals and perennials occur. The important annual species are Acnida cannabina L. (Amaranthus cannabinus (L.) Sauer), Ambrosia trifida L., Bidens laevis (L.) BSP, Cuscuta gronovii Willd., Impatiens capensis Meerb., Pilea pumila (L.) Gray, Polygonum arifolium L., Polygonum punctatum Ell., and Zizania aquatica L. var. aquatica. The important perennials are Acorus calamus L., Nuphar advena (Ait.) Ait., Peltandra virginica (L.) Schott \& Endl., Phalaris arundinacea L., Sagittaria latifolia Willd., Scirpus fluviatilis (Torr.) Gray, Sium suave Walt., and Typha latifolia $\mathrm{L}$.

\section{Materials and methods}

This study was carried out in the Hamilton Marshes, the northernmost tidal freshwater wetland along the Delaware River, located just south of Trenton, New Jersey. Descriptions of the wetland, including vegetation, tidal flux, and other characteristics, have been given by Whigham and Simpson (1975), Simpson et al. (1983), and Parker and Leck (1985). The study site was on the west side of a small tributary of Crosswicks Creek in the general location where earlier seed bank studies had been conducted (Leck and Graveline, 1979; Parker and Leck, 1985; Leck and Simpson, 1987).

On 13 June 1984, eight transects, $5 \mathrm{~m}$ apart, were laid out perpendicular to the stream channel. Six permanent sites were located along each transect, beginning about $0.5 \mathrm{~m}$ from the bottom of the stream channel and at $5 \mathrm{~m}$ intervals. Transects terminated in the high marsh, where inundation at high tide was about $0.1 \mathrm{~m}$. Sites were numbered as follows: 1-stream channel; 2levee; 3-intermediate between the levee and the high marsh; 4-6-high marsh.

\section{Seed rain (input)}

At each of the 48 sites, two seed rain traps were placed about $20 \mathrm{~cm}$ apart on the wetland surface, after removal of any litter. Each trap consisted of two 
$20 \mathrm{~cm} \times 20 \mathrm{~cm}$ layers of fine mesh nylon fabric secured to the wetland surface with six hairpins. Traps were set out on 13 June 1984 and 6 June 1985, well before seed production occurred. Traps, including all sediment deposited on their surfaces, were retrieved on 7-8 March 1985 and 10 March 1986, respectively. Some traps collected in 1986 had little accumulated sediment, perhaps as a result of frost heaving, which had not been a problem in 1985 or in a previous study (Leck and Simpson, 1987). Some of the 1986 traps that had accumulated large amounts of litter were difficult to remove because of ice. Also, because at Site 1 in 1986 most traps had been dislodged, no rain or persistent seed bank data are available for that site.

Traps actually determined seed input, not just seed rain, because some of the dispersal into or out of a site may have been by water transport and/or redispersal. For convenience, the term seed rain is used.

\section{Persistent seed bank}

On 8 March 1985, after each rain trap (see above) had been removed, a soil sample $(10 \mathrm{~cm} \times 10 \mathrm{~cm} \times 2 \mathrm{~cm}$ in depth $)$ was obtained beneath the center of the trap. However, because of possible contamination where traps were dislodged or in places with unconsolidated soil, we were only able to collect the following numbers of samples: Site 1-two samples; Sites 2, 3, 4 and 6four samples; Site 5-three samples. Because of low recovery of traps, 10 surface samples $(10 \mathrm{~cm} \times 10 \mathrm{~cm} \times 2 \mathrm{~cm})$ were also collected at Site 1 on both 8 March and 7 June 1985 . June samples also provide information on seeds persisting for at least 1 year.

\section{Sample treatment}

Each sample was placed in a plastic bag and processed on the same day of collection. Half of the samples from each site were flooded and the other half unflooded, but saturated. All samples were maintained in a greenhouse with ambient photoperiod, about $30 \%$ solar illuminance, and a temperature range of approximately $12-35^{\circ} \mathrm{C}$. They were watered with distilled water and fertilized $(5: 5: 5)$ twice during the growing season. Germination was monitored for 6 months.

Unflooded samples were placed on $2-3 \mathrm{~cm}$ of moistened perlite in aluminum pans of dimensions $20 \mathrm{~cm} \times 20 \mathrm{~cm} \times 4.5 \mathrm{~cm}$ and with drainage holes. Seed rain traps were laid directly on the perlite surface, whereas the persistent seed bank and June surface samples from Site 1 were spread in a layer about $1 \mathrm{~cm}$ in thickness. Flooded samples were placed directly into pans without perlite or drainage holes; water depth was maintained at about $2 \mathrm{~cm}$.

Both the seed rain and the persistent seed bank were estimated from the numbers of seedlings emerging from these samples. Data reported are the 
maximum values for each species at each site; these were usually from the unflooded samples. Numbers of species are based on both flooded and unflooded samples from each site.

\section{Field seedlings and shoot density of perennial species}

On 5 May 1985 and 7 May 1986, at about peak field seedling density (Parker and Leck, 1985), the numbers of seedlings in $20 \mathrm{~cm} \times 20 \mathrm{~cm}$ plots were counted at each of the 48 sampling sites. The shoot numbers for perennials were also determined on 5 May 1985 , using $50 \mathrm{~cm} \times 50 \mathrm{~cm}$ plots.

\section{Seed production}

Seed production patterns, except for Phalaris arundinacea and Nuphar advena, were determined on 5 October 1985 , using $50 \mathrm{~cm} \times 50 \mathrm{~cm}$ plots. The actual method of estimating seed production varied with species. Ambrosia trifida plants were counted; seed estimates were based on an average of 1200 seeds per Ambrosia plant, with a maximum of 11.3 plants $\mathrm{m}^{-2}$ (Sickels and Simpson, 1985). Cuscuta gronovii fruits, each having four seeds (Fernald, 1950), were counted. Impatiens capensis estimates were based on dehisced plus mature fruits, with each fruit containing 2.06 seeds (Simpson et al., 1985). For Nuphar advena and Phalaris arundinacea estimates were based on shoot data collected in May 1985. It was assumed that 25\% of the shoots would be reproductive and that each Nuphar capsule would contain $91 \pm 15$ (SE) seeds ( $n=3$ capsules) and each Phalaris inflorescence would have $452 \pm 38$ seeds ( $n=6$ inflorescences). Each Peltandra virginica pod was counted; each pod was considered to have $25 \pm 2$ single-seeded fruits ( $n=29$ pods). For $P o$ lygonum arifolium and Polygonum punctatum all flowers, containing a singleseeded fruit, were counted and it was assumed that flowers that would not mature would equal those already dispersed. For Pilea pumila, Sagittaria latifolia, and Sium suave the following estimates were used: each Pilea pumila plant was estimated to produce 100 seeds; each Sagittaria latifolia seed-head was estimated to contain 300 seeds; each Sium suave umbel was estimated to have 10 seeds.

To determine seed production patterns conservative estimates were used. Except as noted, we are unaware of other published seed production values on which to base our estimates. On 5 October, when production data were obtained, most species had already begun to disperse seeds, and of the common species, only Phalaris arundinacea dispersal was completed, having occurred late in June.

Nomenclature follows Fernald (1950) except for Zizania aquatica var. aquatica (Gleason, 1952) and Phragmites australis (Cav.) Trin. (Gleason and Cronquist, 1991). Analysis of variance and the Duncan multiple range 
test utilized Statistical Analysis Systems Institute procedures (SAS, 1989). Unless otherwise indicated, the significance level was $P \leq 0.05$.

\section{Results}

Figure 1 illustrates the variable patterns of 13 common annual and perennial species at the six sites; 37 other species also occurred in seed rain and persistent seed bank samples, but were less than $9 \%$ of the seedlings recorded. The seed rain samples contained 42 species in 1985 but only 29 in 1986, related in part to the lack of Site 1 samples in 1986. The persistent seed bank samples contained 25 species. Most species were herbaceous. The exceptions were three shrubby species (Baccharis halimifolia L., one seedling; Cephalanthus occidentalis L., eight seedlings; Physocarpus opulifolius (L.) Maxim., one seedling) and one species of vine (Parthenocissus quinquefolia (L.) Planch., two seedlings) all of which occurred only in seed rain samples. All 17 seedling species that were found in the field also occurred in the greenhouse samples. Of more than 14000 seedlings only 25 could not be identified to genus.

Across all sites seed rain totals were not significantly different. However, totals do not reflect seed rain patterns of individual species (Fig. 1). Significant site differences occurred for Acnida cannabina, Ambrosia trifida, Bidens laevis, Callitriche heterophylla Pursh (not illustrated), Juncus effusus L. (not illustrated ), Impatiens capensis, Polygonum arifolium, and Polygonum punctatum, but not for Cuscuta gronovii, Nuphar advena, Peltandra virginica, Phalaris arundinacea, Pilea pumila, Typha latifolia, and Zizania aquatica var. aquatica. Polygonum arifolium and Impatiens capensis dominated the seed rain at high marsh sites, whereas other species were more important near the stream channel. In 1985 , species diversity declined markedly $(P \leq 0.001)$ from stream channel ( $18 \pm 2$ species per sample) to high marsh sites $(6.6 \pm 0.7$ species per sample at Site 6 ), but the same pattern did not occur in 1986 because Sites 2 and 4 had more species than Sites 3 and 5.

Persistent seed bank values (Fig. 1), ranging from $1675 \pm 1028$ to $5967 \pm 3922 \mathrm{~m}^{-2}$, suggest a large persistent seed reservoir. However, surface samples collected at Site 1 in March and June, with $7788 \pm 1748 \mathrm{~m}^{-2}$ and $688 \pm 348 \mathrm{~m}^{-2}$, respectively, indicate considerable depletion of the seed bank after spring germination; only Acnida cannabina occurred in sizeable numbers in June ( $\left.550 \pm 323 \mathrm{~m}^{-2}\right)$. Interestingly, at Site 1 the persistent seed bank $\left(3550 \pm 1550 \mathrm{~m}^{-2}\right)$, seed rain $\left(5017 \pm 1313 \mathrm{~m}^{-2}\right)$, and March values $\left(7788 \pm 1748 \mathrm{~m}^{-2}\right)$ were comparable, although species composition differed. There were no significant site differences in species diversity, although values ranged from $9.8 \pm 2.5$ (Site 2) to $3.5 \pm 1.2$ (Site 6) species per sample and from $10.5 \pm 2.4$ (Site 2 ) to $4.3 \pm 1.4$ (Site 6 ) total species.

Like seed rain and persistent seed bank totals, field seedling totals were 
similar across sites. Field seedling numbers were significantly higher $(P \leq 0.001)$ in 1985 . Seedling distribution patterns, especially for Acnida cannabina, Ambrosia trifida, Bidens laevis, Polygonum arifolium, and Polygonum punctatum, were like those for the seed rain (Fig. 1). Seedling densities were generally less than seed rain values, except for Acnida cannabina, which produced few seeds (outside plots), and Bidens laevis, which produced no seeds in 1985. Seedling species diversity varied with site $(P \leq 0.01)$, and was higher along the stream channel (in 1985, values ranged from $6.6 \pm 0.6$ per sample at Site 2 to $3.6 \pm 0.4$ at Sites 5 and 6 ). The lowest diversity occurred at Sites 5 and 6 in both years.

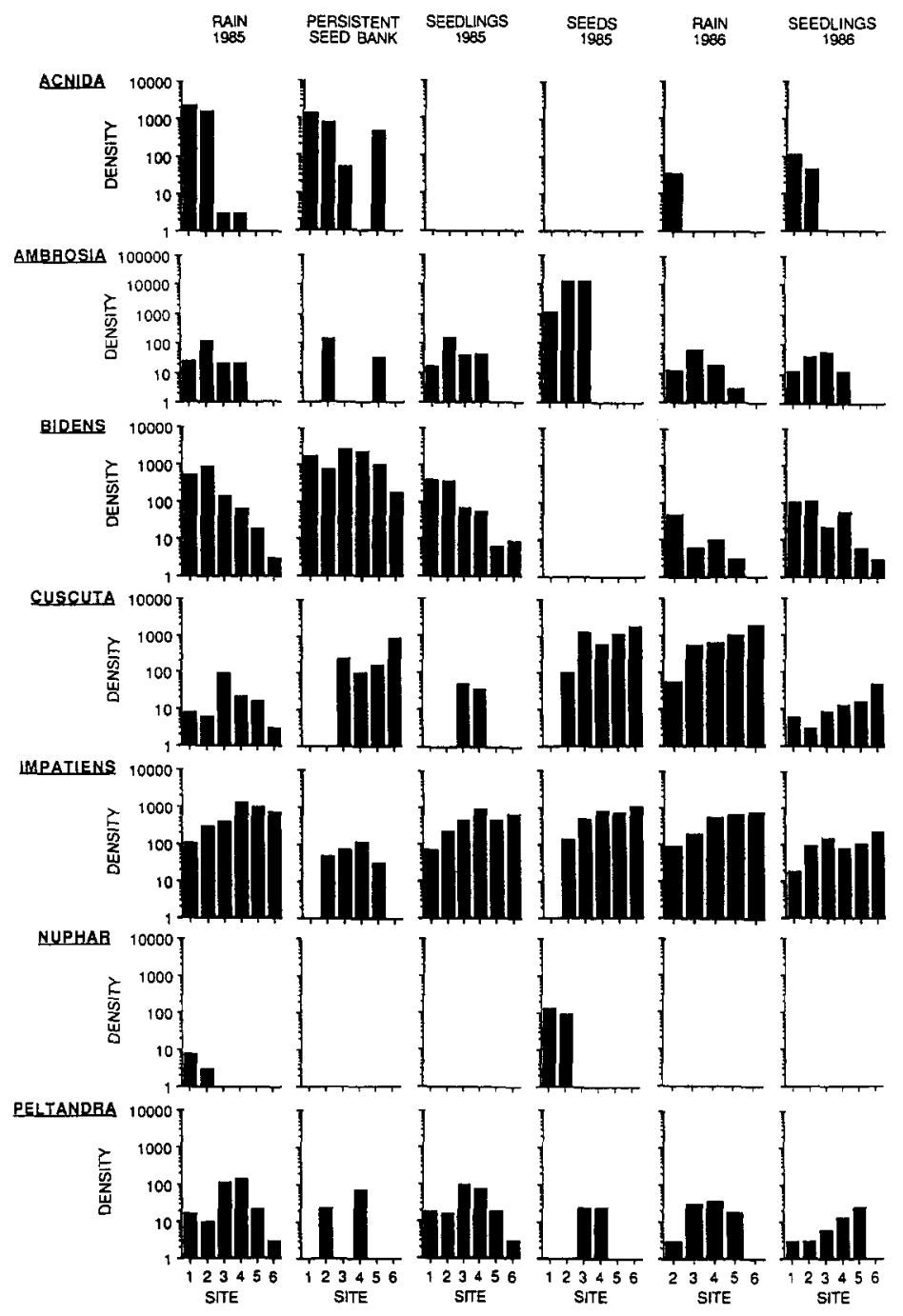




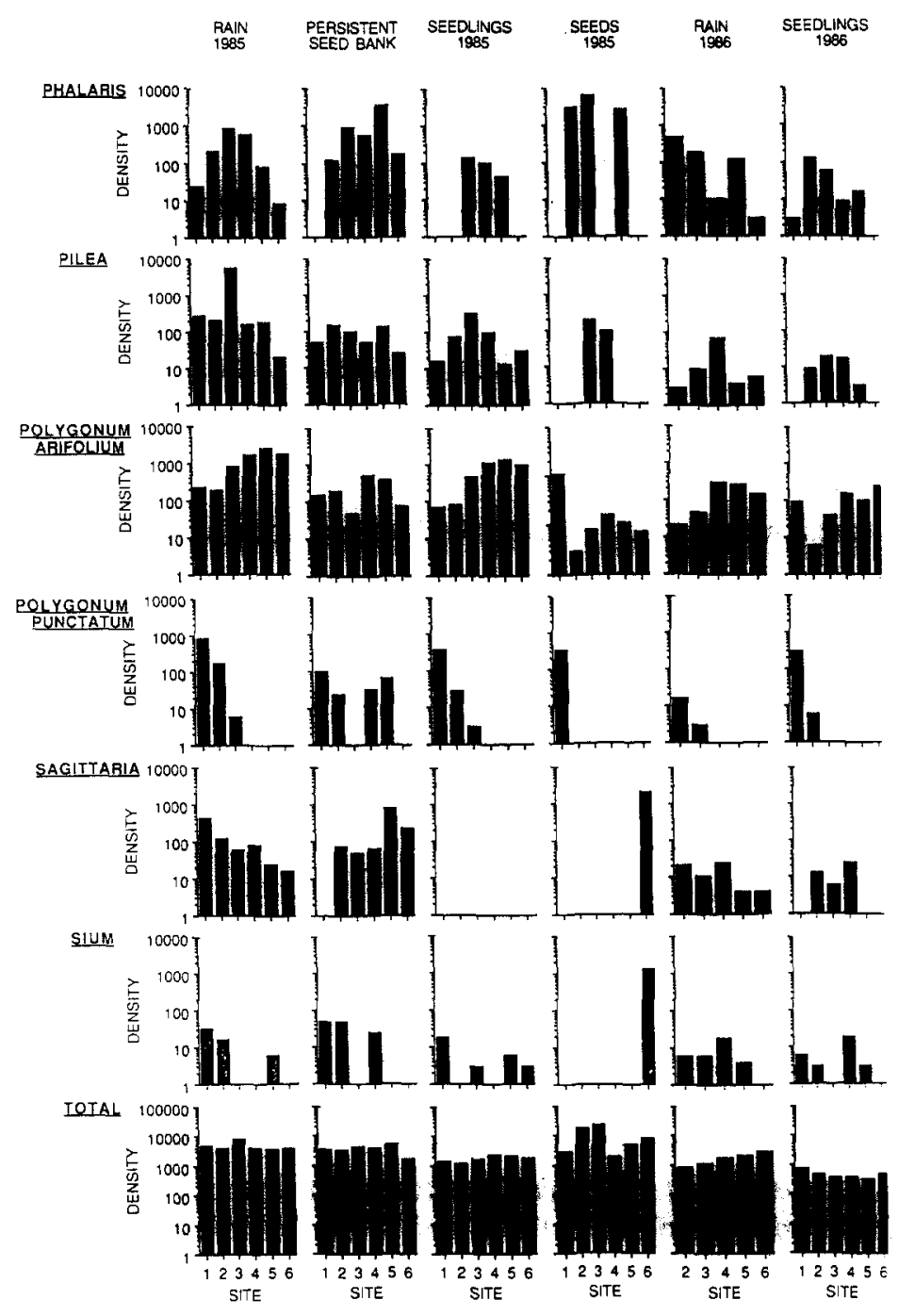

Fig. 1. Seed rain (input) in 1985 and 1986, persistent seed bank, field seedling, and seed production densities (per square meter) for 13 species and totals from a tidal freshwater wetland.

Spatial patterns of seed production, seed rain, and/or seedling densities varied with species and with year. Polygonum arifolium had the highest seed production but lowest seedling density at Site 1 . For most species, the range of sites over which seeds were trapped and seedlings were found was broader than the range of sites over which seed production occurred. For example, Polygonum punctatum produced seeds only at Site 1, but seeds and seedlings occurred at Sites 2-5. Peltandra virginica and Pilea pumila produced seeds only at Sites 3 and 4, but seeds and seedlings were found at all sites. Overall, 
fewer species produced seeds at Sites 1 and $2(P \leq 0.001)$. Zizania aquatica var. aquatica at Site 1 and Typha latifolia near Sites 5 and 6 were the only other species that produced seed in the area that we studied, but did not occur as established plants within the sampling plots.

Not unexpectedly, some species were more abundant at particular sites. $A C$ nida cannabina, Nuphar advena, and Polygonum punctatum were found near the stream channel, whereas Cuscuta gronovii occurred in low numbers near the channel. Polygonum arifolium was most numerous at high marsh sites (Fig. 1), although seed production was highest at Site 1. Zizania aquatica var. aquatica (not illustrated) occurred primarily in the bottom of the stream channel ( $49 \pm 7$ seedlings $\left.\mathrm{m}^{-2}\right)$ and at Site $1\left(37 \pm 22 \mathrm{~m}^{-2}\right)$, but low numbers occurred in rain samples or as seedlings at all other sites.

Field seedling densities ranged from 16 to $63 \%$ of values obtained from rain samples in the greenhouse. Compared with estimated seed production, rain values were $5-99 \%$ of site totals, and field seedlings $2-24 \%$.

Juncus effusus (not illustrated) was the only species found at densities of $100 \mathrm{~m}^{-2}$ or more (maximum $238 \pm 42$ in Site 1 March samples) in rain and persistent seed bank samples that was not also found in the field as seedlings or in the vegetation. It tended to be more common in samples obtained near the stream channel.

Analysis of stem densities for the 10 perennial species present showed no significant yearly differences, except for Scirpus fluviatilis, which was more abundant in 1986. There were significant site differences in total stem density $\left(5.6 \pm 2.0 \mathrm{~m}^{-2}\right.$ at Site 1 and $16 \pm 6.4 \mathrm{~m}^{-2}$ or more at other sites in 1985), species per sample $(0.6 \pm 0.2$ at Site 1 and $1.3 \pm 0.3$ or more at other sites), and for Acorus calamus, Cicuta maculata L., Scirpus fluviatilis, Typha latifolia (all absent from Sites 1 and 2), Phalaris arundinacea (absent from Site 1 ), and Nuphar advena (present only at Sites 1 and 2). There were no significant site differences for Peltandra virginica (not found at Site 1), Sagittaria latifolia, or Sium suave (not found at Sites 1 and 2). Eupatorium sp. was found only at one site.

\section{Discussion}

The vegetation dynamics of communities reflect the life history strategies of individual species, interactions between species, and responses of species to environmental conditions. The surface vegetation of tidal freshwater wetlands displays distinct patterns of zonation (Simpson et al., 1983) that are mirrored in the seed bank (Leck and Graveline, 1979; Parker and Leck, 1985; Leck and Simpson, 1987). These relationships are, however, complex. This study clearly showed that seed rain, seed bank, seedlings observed in the field, and seed production patterns vary between species, across sites for a species, 
and between years (Fig. 1). Because overall community patterns are not strong, we focus discussion on individual species.

(1) Acnida cannabina. Mature Acnida cannabina plants usually occur on stream banks and levees (Simpson et al., 1983). Seed rain and seedling densities were highest in those areas. We found that few seedlings survived to reproduce, although Parker and Leck (1985) found high survivorship in a previous study. Low survival may be associated with competition and shading by the dense stands of Ambrosia trifida and Phalaris arundinacea near the stream channel that were not present in 1979 when the Parker and Leck study was carried out. Because Acnida cannabina may produce few seeds in some years, a persistent seed bank and water dispersal (redispersal?) appear necessary for survival.

(2) Ambrosia trifida. During the study, Ambrosia trifida adults occurred in dense stands along levees (Simpson et al., 1983; Sickels and Simpson, 1985) where seed rain, seedling densities, and seed production rates were also greatest. Some dispersal from the seed production areas occurred (Fig. 1). Although there is some evidence for a persistent seed bank (Fig. 1; Leck and Simpson, 1987), the success of this species appears dependent on extravagant seed production (Fig. 1; Sickels and Simpson, 1985) as less than $1 \%$ of the seeds survive to the seedling stage and even fewer reach reproductive maturity, even though seedlings appear to be able to persist for long periods of time (Parker and Leck, 1985).

(3) Bidens laevis. Adults of this species are most common along stream channels and on the high marsh (Simpson et al., 1983), but population density fluctuates greatly from year to year (Leck et al., 1989; M.A. Leck and R.L. Simpson, unpublished data, 1982-1993). Based on exclosure data, the persistent seed bank at Site 1 (Fig. 1) was large $\left(1800 \pm 1500 \mathrm{~m}^{-2}\right)$, but was essentially non-existent in samples collected in June $\left(13 \pm 13 \mathrm{~m}^{-2}\right)$. This study was conducted during low-density years when seeds and seedlings were present at all sites (Fig. 1), but no seedlings survived to reproduce. In a previous study, Parker and Leck (1985) found high persistence in some areas. Because of years with no seed production, Bidens laevis is dependent on a persistent seed bank and some dispersal. We do not know why survival is low in some years, but the presence of more aggressive species, such as Ambrosia trifida and Phalaris arundinacea, may influence growth and survival, especially at channel sites.

(4) Cuscuta gronovii. This parasite is commonly associated with Impatiens capensis on the high marsh. Seed production and seed rain occurred throughout the high marsh. Seedlings, however, were present in low numbers, with no year-to-year consistency in distribution. A small persistent seed bank (Fig. 1; Leck and Simpson, 1987, unpublished data, 1984) may contribute to field seedlings, and seed production centered in high marsh sites with uniform dis- 
tribution in the seed rain suggests that water dispersal results in uniform dispersal of seeds.

(5) Impatiens capensis. Impatiens capensis is a common high marsh species (Simpson et al., 1983), but its seed rain and seedlings occurred at all sites (Fig. 1). Dispersal from explosive fruits and by water are important. Seed production, however, was restricted to high marsh sites. Although Antlfinger (1989) found a persistent seed bank in a Nebraska floodplain population, the evidence for a persistent seed bank in this wetland has not been corroborated (Leck, 1979; Simpson et al., 1985; Leck and Simpson, 1987). Moreover, few seedlings appeared in soil samples held for 2 years in a greenhouse (M.A. Leck and R.L. Simpson, unpublished data, 1984). However, other data (M.A. Leck unpublished data, 1992) indicate that if after-ripening requirements are not met, some seeds remain viable and germinate in the second spring.

(6) Juncus effusus. Juncus effusus is the only common seed rain or seed bank species that is not also found in the field vegetation. Thus, it appears completely dependent on dispersal, and the very small seeds $(0.01 \mathrm{mg}$; Grime et al., 1981 ) may be readily dispersed by both water and wind. In other studies its presence at depths greater than $30 \mathrm{~cm}$ (Leck and Simpson, 1987; C. Cimpko, personal communication, 1992) suggests longevity exceeding 75 years. It was also found in stream channel samples (as Juncus sp.; Leck and Graveline, 1979; Parker and Leck, 1985) and at a shrub forest site, but high densities at the latter site, near the edge of the marsh, may relate to a different vegetation history there. Lack of establishment may be due to possible later germination of perennials (Leck et al., 1989), lower germination in the shade (Grime et al., 1981), small size of seedlings, and/or some other unknown factor.

(7) Pilea pumila. Based on our observations, Pilea pumila adults are found in slightly elevated locations. Seed rain, seedlings, and the seed bank were widely distributed, but seed production was restricted to Sites 3 and 4 (Fig. 1). This species fluctuates widely, and there appears to be little reliance on a persistent seed bank (also Leck and Simpson, 1987, unpublished data, 1991). Its success only in specific microsites may be related to the small size of seedlings (Leck and Simpson, 1992).

(8) Polygonum arifolium. Adult plants occurred along the entire transect. Seed production, seed rain, and seedling density patterns were similar, although numbers varied from year to year. On the high marsh, the ratio of seed production to field seedlings ranged from 0.9 to 3.3 , indicating a high probability of germination and/or dispersal. This species appears to depend on seed rain and possibly a persistent seed bank, although Leck and Simpson (1987) found little evidence for the latter.

(9) Polygonum punctatum. Adults were found only along the stream channel even though seed rain, seedlings, and persistent seed bank data indicate that it is dispersed widely. Overall dispersal must be limited, however, as the 
previous year's seed production appears overwhelmingly important to population maintenance, with $91 \%$ of the seed production at Site 1 in 1985 appearing as seedlings in 1986.

(10) Nuphar advena and Acorus calamus. Adults of Nuphar advena occurred only in the tidal channel and adjacent banks. Seed production was low in 1985 and lacking in 1986, and no persistent seed bank occurred. It is likely that vegetative reproduction is the most important factor in population maintenance. The same is true for Acorus calamus, which occurs on the high marsh and for which only vegetative reproduction has been observed in this wetland (Leck and Simpson, 1987).

(11) Peltandra virginica. Peltandra virginica is a common perennial, with established plants scattered in high marsh sites (Whigham et al., 1979). Seed production occurred only on the high marsh, but seed rain and seedling data showed that it is a widely distributed species, mostly owing to water dispersal of the large buoyant fruits. Seeds in the seed bank are short lived; seedlings emerged from only two persistent seed bank samples. Whigham et al. (1979) and Leck and Simpson (1987; unpublished data, 1991) also suggested that Peltandra virginica is a transient component of the seed bank (Leck et al., 1989). Unlike Nuphar advena and Acorus calamus, Peltandra virginica does not produce elongate rhizomes, although vegetative development sometimes occurs when branches separate as the basal portion of the rhizome decays (Goldberg, 1941).

(12) Phalaris arundinacea. Since 1974, dense clumps of Phalaris arundinacea have become common in a band extending from the back of the levee into the high marsh. Despite a substantial seed bank and high seed rain, low seedling numbers suggest that population maintenance and expansion are largely by vegetative propagation. Phalaris arundinacea, Callitriche heterophylla, and Gratiola neglecta Torr. are the only species at this study site that do not produce seed in late summer and autumn. Germination of fresh Phalaris arundinacea seeds ( $49 \%$ within 1 month at $10-15^{\circ} \mathrm{C}$ in light; M.A. Leck, unpublished data, 1990) suggests that seedlings could become established during the summer or autumn in gaps which occur when leaf cover declines or lodging occurs.

(13) Sagittaria latifolia. Sagittaria latifolia has a scattered distribution in all areas except stream channels. Field seedlings were absent in 1985 and present in low densities in 1986 despite evidence for dispersal and a persistent seed bank (Fig. 1). This suggests that vegetative reproduction plays a major role in population maintenance, probably through the production of tubers (Sculthorpe, 1967). However, like Phalaris arundinacea, exploitation of gaps by seedlings may occur because germination phenology of perennials lags behind that of annuals (Leck et al., 1989); field germination of Sagittaria latifolia was 1-1.5 months later than that of most other species (V.T. Parker and M.A. Leck, unpublished data, 1979). 
(14) Sium suave. Adults of Sium suave, a low-density perennial, occurred mostly on the high marsh. Seed production values (Fig. 1) reflect its patchy distribution, but seed rain, seedlings, and persistent seed bank data suggest that dispersal occurs throughout. Sium suave appears to depend on dispersal and persistence in the seed bank, and has, in fact, increased in occurrence in the study area.

Despite distinct species differences across zones, the seed rain and seed bank totals for each site were similar (Fig. 1). Year-to-year variations were notable, with significantly more seed rain and seedlings occurring in 1985. These variations are within the range found for a nearby site over 10 years (M.A. Leck and R.L. Simpson, unpublished data, 1982-1993). However, soil samples from beneath exclosures (persistent seed bank; Fig. 1) contained sizeable numbers of seeds.

Comparison of seed production and rain patterns (Fig. 1) indicates dispersal between sites, and for Acnida cannabina and Bidens laevis, presence in the 1986 rain suggests extrasite dispersal and/or redispersal from the persistent seed bank. It is possible that seed traps were not securely in place through the winter, and water and ice movement caused relocation of seeds (animal activity was not observed ), but this seems unlikely, given the amount of sediment accumulated on the surface of the traps.

The seed bank of this freshwater tidal wetland is dynamic, ultimately influenced by a combination of seed production, dispersal, and seed persistence. It is, as noted by Parker et al. (1989), highly integrated into population and community dynamics. Four general strategies are apparent for the species present: (1) reliance on yearly seed production, and to a lesser extent dispersal, to perpetuate the population (the annuals Ambrosia trifida, Cuscuta gronovii, Impatiens capensis, Pilea pumila, Polygonum arifolium, and Polygonum punctatum, and the perennial Peltandra virginica); (2) reliance on a persistent seed bank and dispersal for population maintenance (the annuals Acnida cannabina and Bidens laevis, and the perennial Sium suave); (3) reliance on vegetative reproduction and/or gap exploitation later in the growing season by seedlings, although a substantial seed bank may be formed (the perennials Nuphar advena, Phalaris arundinacea, and Sagittaria latifolia); (4) continuing dispersal into the site and a potentially very long-lived seed bank with no current contribution to the vegetation (the perennial Juncus effusus).

In this wetland a large component of the seed bank is transient (Leck and Simpson, 1987), in contrast to the situation in, for example, prairie glacial marshes (Van der Valk and Davis, 1978; Van der Valk, 1981), bogs (McGraw, 1987), and exposed mud (Salisbury, 1970). Thus, the seed bank and important life history characteristics (Van der Valk, 1981) differ qualitatively in importance from those of other wetlands where the inundation cycle is not predictable (e.g. Van der Valk, 1981; McCarthy, 1987; Middleton et al., $1991)$. 
The potential flora of this wetland is sizeable (about 115 species), yet only 30 seedling species have been observed in the field (Leck and Simpson, 1993). (Two common species, Scirpus fluviatilis and Acorus calamus, do not produce seeds locally.) Such a difference between actual and potential flora was also noted by Van der Valk (1981). Moreover, for many species, presence in the seed bank is transitory (Leck and Simpson, 1987).

Species distribution represents a continuum of tolerances to physical, chemical, and biotic environment (Leck, 1989). However, zonation was not sharply discontinuous (Fig. 1), similar to that of other freshwater wetlands (Odum et al., 1984; Johnson et al., 1987). Except for Nuphar advena, species extended over several sites. Species with seedlings and adult plants near the stream channel tolerate physical stresses better than those which survive on the high marsh (Parker and Leck, 1985; Johnson et al., 1987). Sediment composition appears uniform, so recruitment is probably most affected by inundation and scouring, but not particle size (Wilson and Keddy, 1985; Keddy and Constabel, 1986). However, physiological responses of species to a physical gradient alone are insufficient to account for zonation; competition, therefore, is involved (Wilson and Keddy, 1985). We would like to emphasize that, as noted by Keddy and Ellis (1985), mechanisms resulting in wetland distribution patterns cannot be determined by examining the distribution of adult plants. Recruitment is affected by many factors, including moisture regime (e.g. Van der Valk and Davis, 1978; Van der Valk, 1981; Keddy and Ellis, 1985), substrate (Keddy and Constabel, 1986), burial (Galinato and Van der Valk, 1986), and litter (Van der Valk, 1986). Recruitment and seedling characteristics are especially important in this annualdominated wetland.

\section{Acknowledgments}

H.F. Buell, D.F. Whigham, and C.F. Leck made many helpful comments on earlier versions of the manuscript.

\section{References}

Antlfinger, A.E., 1989. Seed bank, survivorship, and size distribution of a Nebraska population of Impatiens capensis (Balsaminaceae). Am. J. Bot., 76: 222-230.

Fernald, M.L., 1950. Gray's Manual of Botany. American Book Co., New York, 1632 pp.

Galinato, M.I. and van der Valk, A.G., 1986. Seed germination traits of annuals and emergents recruited during drawdowns in the Delta Marsh, Manitoba, Canada. Aquat. Bot., 26: 89102.

Gleason, H.A., 1952. The New Britton and Brown Illustrated Flora of the Northeastern United States and Adjacent Canada. Vol. 1. Hafner, New York, 482 pp.

Gleason, H.A. and Cronquist, A., 1991. Manual of Vascular Plants of Northeastern United States and Adjacent Canada. New York Botanical Garden, Bronx, New York, 910 pp. 
Grime, J.P., Mason, G., Curtis, A.V., Rodman, J., Band, S.R., Mowforth, M.A.G., Neal, A.M. and Shaw, S., 1981. A comparative study of germination characteristics in a local flora. J. Ecol., 69: 1017-1059.

Goldberg, B., 1941. Life history of Peltandra virginica. Bot. Gaz., 102: 641-662.

Johnson, C.W., Sharik, T.L., Mayes, R.A. and Smith, E.P., 1987. Nature and cause of zonation discreteness around glacial prairie marshes. Can. J. Bot., 65: 1622-1632.

Keddy, P.A. and Constabel, P., 1986. Germination of ten shoreline plants in relation to seed size, particle size, and water level: an experimental study. J. Ecol., 74: 133-141.

Keddy, P.A. and Ellis, T.H., 1985. Seedling recruitment of 11 wetland plant species along a water gradient: shared or distinct responses? Can. J. Bot., 63: 1876-1879.

Leck, M.A., 1979. Germination behavior of Impatiens capensis Meerb. (Balsaminaceae). Bartonia, $46: 1-14$.

Leck, M.A., 1989. Wetland seed banks. In: M.A. Leck, V.T. Parker and R.L. Simpson (Editors), Ecology of Soil Seed Banks. Academic Press, San Diego, CA, pp. 283-305.

Leck, M.A. and Graveline, K.J., 1979. The seed bank of a freshwater tidal marsh. Am. J. Bot., 66: 1006-1015.

Leck, M.A. and Simpson, R.L., 1987. Seed bank of a freshwater tidal wetland: turnover and relationship to vegetation change. Am. J. Bot., 74: 360-370.

Leck, M.A. and Simpson, R.L., 1993. Seeds and seedlings of the Hamilton Marshes, a Delaware River tidal freshwater wetland. Proc. Acad. Nat. Sci. Philadelphia, 144: 267-281.

Leck, M.A., Simpson, R.L. and Parker, V.T., 1989. The seed bank of a freshwater tidal wetland and its relationship to vegetation dynamics. In: R.R. Sharitz and J.W. Gibbons (Editors), Freshwater Wetlands and Wildlife. USDOE Office of Scientific and Technical Information, Oak Ridge, TN, pp. 198-205.

McCarthy, K.A.. 1987. Spatial and temporal distributions of species in two intermittent ponds in Atlantic County, New Jersey. M.Sc. Thesis, Rutgers University, Piscataway, NJ, 103 pp.

McGraw, J.B., 1987. Seed bank properties of an Appalachian sphagnum bog and a model of the depth distribution of viable seeds. Can. J. Bot., 65: 2028-2035.

Middleton, B.A., van der Valk, A.G., Mason, D.H., Williams, R.L. and Davis, C.B., 1991. Vegetation dynamics and seed banks of a monsoonal wetland overgrown with Paspalum distichum L. in northern India. Aquat. Bot., 40: 239-259.

Odum, W.E., Smith, III, T.J., Hoover, J.K. and McIvor, C.C., 1984. The ecology of tidal freshwater marshes of the United States east coast: a community profile. US Fish Wildl. Serv., FWS/OBS-83/17, Washington, DC 177 pp.

Parker, V.T. and Leck, M.A., 1985. Relationship of seed banks to plant distribution patterns in a freshwater tidal wetland. Am. J. Bot., 72: 161-174.

Parker, V.T., Simpson, R.L. and Leck, M.A., 1989. Pattern and process in the dynamics of seed banks. In: M.A. Leck, V.T. Parker and R.L. Simpson (Editors), Ecology of Soil Seed Banks. Academic Press, San Diego, CA, pp. 367-384.

Salisbury, E., 1970. The pioneer vegetation of exposed muds and its biological features. Philos. Trans. R. Soc. London, Ser. B, 259: 207-255.

Sculthorpe, C.D., 1967. The Biology of Aquatic Vascular Plants. Edward Arnold, London, 610 pp.

Sickels, F.A. and Simpson, R.L., 1985. Growth and survival of giant ragweed (Ambrosia trifida L.) in a Delaware River freshwater tidal wetland. Bull. Torrey Bot. Club, 112: 368-375.

Simpson, R.L., Good, R.E., Leck, M.A. and Whigham, D.F., 1983. The ecology of freshwater tidal wetlands. BioScience, 33: 255-259.

Simpson, R.L., Leck, M.A. and Parker, V.T., 1985. The comparative ecology of Impatiens capensis in central New Jersey. Bull. Torrey Bot. Club, 112: 295-311.

Statistical Analysis Systems Institute (SAS), 1989. SAS User's Guide: Statistics. SAS Institute, Cary, NC, 584 pp. 
Thompson, K. and Grime, J.P., 1979. Seasonal variation in the seed banks of herbaceous species in ten contrasting habitats. J. Ecol., 67: 893-921.

Van der Valk, A.G., 1981. Succession in wetlands: a Gleasonian approach. Ecology, 62: 688696.

Van der Valk, A.G., 1986. The impact of litter and annual plants on recruitment from the seed bank of a lacustrine wetland. Aquat. Bot., 24: 13-26.

Van der Valk, A.G. and Davis, C.B., 1978. The role of seed banks in the vegetation dynamics of prairie glacial marshes. Ecology, 59: 322-335.

Whigham, D.F. and Simpson, R.L., 1975. Ecological studies of the Hamilton Marshes. Progress Report for the Period June 1974-January 1975. Biology Department, Rider College, Lawrenceville, $\mathrm{NJ}, 185 \mathrm{pp}$.

Whigham, D.F., Simpson, R.L. and Leck, M.A., 1979. The distribution of seeds, and seedlings of arrow arum (Peltandra virginica (L.) Kunth) in a freshwater tidal wetland. Bull. Torrey Bot. Club, 106: 193-199.

Wilson, S.D. and Keddy, P.A., 1985. Plant zonation on a shoreline gradient: physiological response curves of component species. J. Ecol., 73: 851-860. 